\title{
PERAN ORANG TUA DALAM MENYIKAPI DAMPAK PERKEMBANGAN TEKNOLOGI BAGI ANAK
}

\author{
Ahmad Zubaidi \\ Universitas Nurul Jadid probolinggo Indonesia \\ ediyan8@gmail.com \\ Hambali \\ Universitas Nurul Jadid probolinggo Indonesia \\ hambali.amien@gmail.com \\ Sania Nur Hafita \\ Universitas Nurul Jadid probolinggo Indonesia \\ sanianurhafita02@gmail.com
}

\begin{abstract}
This study aims to analyze and examine the role of parents in responding to the development of technology for children. This research method uses a case study approach in Pakuniran Village, Pakuniran District, Probolinggo Regency. Collecting data used by means of surveys, interviews, and documentation. While the data analysis techniques were carried out using data collection, data editing, data presentation and conclusion of research results. The results of this study state that the role of parents in dealing with increasingly sophisticated technological developments is by: understanding all applications on gadgets, providing educational rewards, and providing intensive supervision and assistance. It was found that there
\end{abstract}


is a need for intensive supervision and assistance from parents to reduce and prevent the negative impact of gadgets on children.

Keywords: The Role of Parents, Technological Development

\section{Pendahuluan}

Perkembangan teknologi saat ini semakin pesat, dari perkembangan komputer, munculnya internet, gadget (ponsel) yang meriliskan jam digital, hingga situs jejaring sosial ${ }^{1}$. Perkembangan teknologi telekomunikasi yang semakin maju ini juga menyebabkan semakin hilangnya jarak yang memisahkan antara individu satu dengan individu yang lain, sehingga transfer ilmu pengetahuan akan semakin cepat terjadi ${ }^{2}$. Teknologi informasi memacu suatu cara baru dalam kehidupan, dari kehidupan dimulai sampai dengan berakhir, kehidupan seperti ini dikenal dengan e-life, artinya kehidupan ini sudah dipengaruhi oleh berbagai kebutuhan secara elektronik ${ }^{3}$. Zaman sekarang ini, masyarakat tidak bisa lepas dari kemajuan teknologi mulai dari anakanak hingga orang dewasa. Hampir semua manusia sudah mengetahui dan memaanfaatkan teknologi infomasi dan komunikasi dalam kehidupannya. Teknologi sangat membantu untuk mempermudah pekejaan dan kebutuhan sehari-hari ${ }^{4}$.

Salah satu teknologi yang berpengaruh dalam aktivitas keseharian anak, yaitu teknologi informasi dan teknologi yang berupa gadget ${ }^{5}$. Teknologi dalam pendidikan salah satu cara yang sistematis dalam mendesain, melaksanakan, dan mengevaluasi proses keseluruhan dari belajar dan pembelajaran dalam bentuk tujuan pembelajaran yang

\footnotetext{
${ }^{1}$ Abd Hamid Wahid et al., "Information Technology in the Development of Language Aspects of Early Childhood," 2021.

2 Robby Darwis Nasution, "Effect of the Development of Communication Information Technology on Local Cultural Existence," Jurnal Penelitian Komunikasi Dan Opini Publik 21, no. 1 (2017): 30-42.

${ }^{3}$ Brigitta Bondy et al., "Cytosolic Free $[\mathrm{Ca} 2+]$ in Mononuclear Blood Cells from Demented Patients and Healthy Controls," European Archives of Psychiatry and Clinical Neuroscience 243, no. 5 (1994): 224-28, https://doi.org/10.1007/BF02191578.

${ }^{4}$ Irkham Abdaul Huda, "Perkembangan Teknologi Informasi Dan Komunikasi (Tik) Terhadap Kualitas Pembelajaran Di Sekolah Dasar," Jurnal Pendidikan Dan Konseling (JPDK) 2, no. 1 (2020): 121-25, https://doi.org/10.31004/jpdk.v1i2.622.

${ }^{5}$ Eka Mahmud et al., "The Effect of Using Edmodo Application on Students' Mastery Skill of Technology," Journal of Physics: Conference Series 1899, no. 1 (2021), https://doi.org/10.1088/1742-6596/1899/1/012157.
} 
spesifik $^{6}$. Teknologi komunikasi juga dapat dipandang sebagai penerapan prinsip-prinsip keilmuan komunikasi melalui penciptaan material (alatalat teknis) agar meningkatkan kualitas dan kuantitas peranan unsurunsur komunikasi seperti sumber pesan, media, sasaran, dampak sesuai dengan konteks komunikasi, dalam cara pandang ilmu komunikasi, teknologi komunikasi merupakan suatu sistem makro yang didalamnya meliputi teknologi telekomunikasi, teknologi elektronika, dan TI'.

Teknologi di Indonesia saat ini sangat besar pengaruhnya terhadap dunia pendidikan. banyak mempengaruhi dunia pendidikan. Teknologi komunikasi dan informasi digunakan oleh mayarakat dalam mengalirkan data atau pesan yang sepenuhnya bertujuan membantu menangani masalah masyarakat (aktifitas sosial) agar tercapai tujuan komunikasi ${ }^{8}$. Teknologi yang membawa perubahan pada manusia diera digital salah satunya gadget. Dalam situasi diera digital saat ini setiap orang di seluruh dunia sudah pasti memiliki gadget. Dalam penggunaan gadget tidak hanya dari kalangan remaja atau dewasa tetapi hampir semua kalangan, termasuk anak-anak yang masih dalam pengawasan orang tua. Anak-anak yang lahir pada era digital saat ini hidup di dunia di mana teknologi terintegrasi dengan kehidupan sehari hari. ${ }^{9}$

Penggunaan terus menerus akan mempengaruhi standar perilaku mereka sehingga anak akan sangat bergantung dalam aktivitas sehari-hari. Di zaman teknologi ini, terlihat bahwa anak-anak lebih suka bermain dengan gadget dari pada belajar dan berinteraksi sosial ${ }^{10}$. Hal ini menegaskan, karena di masa muda mereka masih temperamental, memiliki rasa ingin tahu yang sangat tinggi, serta mempengaruhi perkembangan imajinasi anak. Oleh karena itu, penggunaan gadget perlu pertimbangan khusus nagii para orang tua. Gadget memiliki nilai yang baik dan manfaat bagi orang tertentu. Tetapi banyak dampak negatif yang timbul dalam pemanfaatan gadget berlebihan untuk remaja, anak-

6 Amin Akbar and Nia Noviani, "Tantangan Dan Solusi Dalam Perkembangan Teknologi Pendidikan Di Indonesia," Prosiding Seminar Nasional Pendidikan Program Pascasarjana Universitas Pgri Palembang 2, no. 1 (2019): 18-25.

${ }^{7}$ Daryanto Setiawan, "Dampak Perkembangan Teknologi Informasi Dan Komunikasi Terhadap Budaya," JURNAL SIMBOLIKA: Research and Learning in Communication Study 4, no. 1 (2018): 62, https://doi.org/10.31289/simbollika.v4i1.1474.

${ }^{8}$ Hasan Baharun et al., "Learning Strategies for Mobile-Assisted Seamless Learning: A Students 'Initial Perceptions" 536, no. Icsteir 2020 (2021): 557-60.

${ }^{9}$ Ria Novianti et al., "Meningkatkan Pengetahuan Orang Tua Dalam Mendidik Anak Di Era Digital Di Kecamatan Koto Gasib Kabupaten Siak Provinsi Riau," Riau Journal of Empowerment 3, no. 3 (2020): 183-90, https://doi.org/10.31258/raje.3.3.183-190.

10 Hasan Baharun et al., "Learning Effectiveness Improvement Through Mobile Learning," Turkish Online Journal of Qualitative Inquiry 12, no. 4 (2021): 1661-65. 
anak, dan bahkan balita. ${ }^{11}$ Oleh karena itu, orang tua memiliki peran yang sangat penting untuk mengatasi penggunaan gadget yang berlebihan pada anak melalui instruksi pendidikan agama dalam keluarga.

Pada masa pandemi COVID-19 saat ini, pembelajaran yang dilakukan secara daring (dalam jaringan) menghadirkan tantangan baru. Orang tua berperan penting dalam membatasi penggunaan teknologi digital. Jangan sampai orang tua mengandalkan gadget untuk menemani anak dan membiarkan anak menggunakan gadget dalam segala kegiatan ${ }^{12}$. Salah satu cara yang efektif bagi orang tua yakni harus selalu mengontrol setiap konten yang ada di gadget anak. Orang tua hendaknya lebih sering mengajak anak untuk berdiskusi, serta tanya jawab seputar aktivitas anak ketika ada waktu luang. Bermain bersama atau hanya sekedar bercanda disela-sela aktivitas yang padat. Dengan begitu anak bisa meniru tingkah laku orang dewasa mengembangkan daya imajinasi dan kreatifitasnya.

Dampak gadget dapat dibagi dua, yakni dampak negatif dan positif. Dampak negatifnya antara lain dapat mengganggu konsentrasi anak, sulit untuk bersosialisasi, membuat kondisi kesehatan mereka kurang baik. Namun disisi positif keberadaan gadget juga dapat membantu bagaimana orang tua menemani anak-anak mereka belajar, tidak khawatir bermain di luar rumah apalagi di lingkungan yang tidak sehat secara fisik dan mental. ${ }^{13}$

Terkait dampak yang ditimbulkan oleh gadget, fenomena yang sering terjadi di desa Pakuniran, kecamatan pakuniran, kabupaten probolinggo, terdapat anak yang lebih asik bermain gadget daripada mendengarkan perintah orang tua, bahkan seringkali ada yang marah jika diperintah oleh orang tua. Anak lebih mementingkan benda mati dari pada dunia nyatanya. Hal yang lebih buruk lagi terjadi apabila anak sudah asik dengan gadget, anak-anak sering tidak memperdulikan siapa yang ada di sekitarnya. Dari permasalahan tersebut, orang tua diharapkan mampu untuk melindungi anak dari ancaman dampak negatif digital tetapi tidak menghalangi manfaat yang bisa didapatkan.

\footnotetext{
${ }^{11}$ Devi Wahyu Setiawati Fredik Melkias Boiliu, Kaleb Samalinggai, "Peran Pendidikan Agama Kristen Di Era Digital Sebagai Upaya Mengatasi Penggunaan Gadget Yang Berlebihan Pada Anak Dalam Keluarga Di Era Disrupsi 4.0," Jurnal DID ACGE 1, no. 1 (2020): 25-28.

${ }^{12}$ Fathor Rozi et al., "Distance Learning and Independent Learning of Students in Higher Education," Journal of Physics: Conference Series 1899, no. 1 (2021), https://doi.org/10.1088/1742-6596/1899/1/012177.

${ }^{13}$ Rahma Hidayati, "Peran Orang Tua: Komunikasi Tatap Muka Dalam Mengawal Dampak Gadget Pada Masa Golden Age," SOURCE: Jurnal Ilmu Komunikasi 5, no. 2 (2020): 1-10, https://doi.org/10.35308/source.v5i2.1396.
} 
Apabila orang tua memberikan kebebasan pada anak dalam mengkonsumsi gadget dan tidak digunakan dengan bijak maka lambat laun akan memberikan dampak negative, seperti kecanduan dengan gadget, kurangnya bersosial dengan orang disekitar dan kurangnya sikap sopan santun. Berdasarkan hal tersebut, diperlukan cara untuk menyikapi dampak media sosial dikalangan remaja terutama dalam perkembangan kepribadian remaja awal atau kanak-kanak akhir. Perlunya peran orang tua sebagai figur, monitor dan pengendali dalam penggunaan media sosial secara bijak dan bertanggung jawab. ${ }^{14}$

Menurut Agustien Lilawati, peran orang tua merupakan menjadi orang tua yang memotivasi dalam segala hal. Memotivasi dapat diberikan dengan cara yang meningkatkan kebutuhan sekolah dan memberikan semangat dalam pujian atau penghargaan untuk prestasi anak. ${ }^{15}$ Sedangkan menurut Efrianus, tugas dan peran orang tua adalah unit dan institusi pertama di dalam masyarakat di mana hubungan-hubungan yang terdapat didalamnya sebagian besar bersifat langsung. ${ }^{16}$ Studi penelitian lain memaparkan bahwa pemanfaatan gadget sebagai edukasi untuk permainan, mengaji, mewarnai, menggambar, dan berhitung, sedangkan peran orang tua hanya difokuskan pada pendampingan sesuai platform yang sesuai karakter anak PAUD, penelitian ini berusaha untuk mengungkap penggunaan gadget yang sesuai dengan usia PAUD. ${ }^{17}$

Penelitian terdahulu fokus terhadap bagaimana cara memotivasi anak sehingga menimbulkan semangat diri dari setiap anak. Perbedaan penelitian ini terletak pada tindakan orang tua dalam menangani anak agar tidak kecanduan gadget. Pembaharuan yang dilakukan dalam penelitian ini dapat diterapkan oleh orang tua melalui pemberian reward agar anak tidak terpacu pada gadget. Hal tersebut sangat penting untuk diteliti guna mencegah dampak negatif gadget terhadap anak. Adapun keunikan dalam penelitian ini terletak pada sikap dan tindakan orang tua terhadap anak untuk tidak terlalu membiasakan anak bermain gadget tanpa menghilangkan manfaat dari teknologi itu sendiri.

\footnotetext{
${ }^{14}$ Wahyu Relisa Ningrum, "Peran Orangtua Dalam Menyikapi Dampak Media Sosial Terhadap Perkembangan Kepribadian Remaja Awal,” 2018, 355-66.

${ }^{15}$ Agustin Lilawati, "Peran Orang Tua Dalam Mendukung Kegiatan Pembelajaran Di Rumah Pada Masa Pandemi," Jurnal Obsesi : Jurnal Pendidikan Anak Usia Dini 5, no. 1 (2020): 549, https://doi.org/10.31004/obsesi.v5i1.630.

${ }^{16}$ Efrianus Ruli, “Tugas Dan Peran Orang Tua Dalam Mendidk Anak," Jurnal Edukasi Nonformal 1, no. 2 (2020): 143-46, https://ummaspul.ejournal.id/JENFOL/article/view/428.

${ }^{17}$ Luluk Asmawati, "Peran Orang Tua Dalam Pemanfaatan Teknologi Digital Pada Anak Usia Dini," Jurnal Obsesi : Jurnal Pendidikan Anak Usia Dini 6, no. 1 (2021): 82-96, https://doi.org/10.31004/obsesi.v6i1.1170.
} 
Penelitian ini menggunakan pendekatan kualitatif sedangkan jenis penelitian yang digunakan adalah metode studi kasus. Metodologi ini dipilih untuk menginspeksi gejala social dengan menelaah satu kasus secara mendalam dan utuh dari berbagai informs yang ditemukan di sekitar.Menurut Cresswell yang dikutip oleh Tutik Rachmawati penelitian kualitatif lebih menarik terutama karena pekerjaan meneliti melibatkan banyak kegiatan-kegiatan empiric seperti studi kasus (case studi), pengalaman-pengalaman pribadi (personal experience), hasil intropeksi (introspective), cerita hidup (life story), wawancara (interview), observasi (observational), sejarah (historical), interaksi (interactional), dan teks-teks visual (visual texts) yang menggambarkan rutinitas dan peristiwaperistiwa problematis dan yang berarti bagi kehidupan-kehidupan individu manusia. ${ }^{18}$ Penelitian ini bertujuan untuk mengetahui seberapa pengaruhnya dampak teknologi bagi anak saat ini.

Penelitian ini dilakukan di lingkungan masyarakat terutama orang tua yang memiliki anak yang masih duduk di Sekolah Dasar di desa Pakuniran, Kecamatan Pakuniran, Kabupaten Probolinggo. Penelitian ini menggunakan teknik pengumpulan data dengan cara survei, wawancara dan dokumentasi. Melalui analisis data, tahapan yang digunakan antara lain pengumpulan data, reduksi data, penyajian data, dan penyimpulan hasil penelitian. Menurut Miles dan Huberman yang dikutip oleh Ahmad Rijali menggambarkan proses analisis data penelitian kualitatif tersebut memperlihatkan sifat interaktif pengumpulan data dengan analisis data. pengumpulan data merupakan bagian integral dari kegiatan analisis data. Reduksi data adalah upaya menyimpulkan data, kemudian memilah-milah data dalam satuan konsep tertentu , kategori tertentu dan tema tertentu. ${ }^{19}$

\section{Hasil dan Pembahasan}

Orang Tua memiliki peran yang sangat penting dalam kehidupan dan perkembagan anak. Mendidik, mengasuh, memelihara, membimbing, melatih atau apapun yang berkaitan dengan usaha untuk mencapai pertumbuhan ke arah yang lebih baik, tentu adalah tanggung jawab setiap orang tua terhadap anaknya. ${ }^{20}$

\footnotetext{
${ }^{18}$ Rachmawati and Tutik, "Metode Pengumpulan Data Dalam Penelitian," Universitas Katolike Parabyangan 1, no. 1 (2017): 1 1-3, http:// ciputrauceo.net/blog/2016/2/18/metode-pengumpulan-data-dalam-penelitian.

19 Ahmad Rijali, "Analisis Data Kualitatif," Alhadharah: Jurnal Ilmu Dakwah 17, no. 33 (2019): 81, https://doi.org/10.18592/alhadharah.v17i33.2374.

${ }^{20}$ Nur Jannah and Khoirul Anam, "Peran Orang Tua Dalam Pendidikan Karakter Berbasis Keluarga Di Masa Pandemi,” Jurnal Studi Keislaman 12, no. 1 (2021): 95-115.
} 
Orang Tua adalah pendidik bagi seorang anak, orang tua diberikan anugerah oleh Allah SWT sebagai sensasi bagi anak-anaknya, sehingga keduanya memiliki rasa kewajiban terhadap keturunannya. Mendidik anak merupakan peran orang tua yang paling utama karena pendidikan anak pertama kali didapat dalam keluarga. Menurut Jones dan Wilkins yang dikutip oleh Arif Wijayanto menyatakan bahwa pengalaman sosialisasi anak-anak yang pertama terjadi dalam keluarganya,oleh karena itu orang tua secara khusus merupakan agen sosial pertama dan utama. ${ }^{21}$

Proses kehidupan dalam sebuah keluarga jelas merupakan interaksi utama sebelum mereka memasuki lingkungan sekolah dan lingkungan masyarakat, karena orang tua memiliki kewajiban dalam hal mendidik anak-anaknya agar menjadi anak yang cemerlang baik secara skolastik maupun nonakademik.

Mengasuh anak memerlukan pola pengasuhan positif terhadap anak. Mengasuh anak harus dilakukan dengan pendidikan yang baik, jika dilakukan dengan yang salah maka akan berdampak yang tidak baik pada perkembangan jiwanya dan raganya, dan tentunya akan berdampak pada lingkungan sekitarnya. ${ }^{22} \mathrm{Hal}$ ini juga tentu dapat kita lihat di sekitar kita yang sering melihat fenomena-fenomena anak yang sudah tak peduli dengan keadaan sekitar disebabkan adanya perkembangan teknologi yang semakin canggih terutamanya gadget.

Selain itu seorang anak memiliki hak istimewa untuk mendapatkan asuhan, khususnya melatih dan merawat anak. Yang dimaksud dengan pemeliharan di sini dapat berupa pengawasan dan perawatan untuk kesehatan fisik dan mental anak dari berbagai risiko yang mungkin menimpa mereka sehingga mereka berkembang secara normal. Dari beberapa kebutuhan misalnya, memenuhi kebutuhan anak akan makanan yang bergizi dan baik, menerapkan aturan dan kebajikan dalam kehidupan anak juga menjadi peran orang tua.

Membimbing atau mengarahkan anak kejenjang pendidikan mulai dari PAUD hingga pendidikan lanjutan. Peran ini sangat dibutuhkan saat ini apalagi di zaman yang semakin kompleks, bahkan orang tua sekalipun tidak akan bisa melarangnya untuk menggunakan gadget. Orang tua yang paling bijaksana selalu mengarahkankan anak untuk digunakan dalam hal positif. Peran orang tua dalam membimbing anak-anak sudah pasti, apalagi di masa pandemi virus Corona saat ini sekolah mulai melakukan

21 Arif Wijayanto, "Peran Orangtua Dalam Mengembangkan Kecerdasan Emosional Anak Usia Dini," Diklus: Jurnal Pendidikan Luar Sekolah 4, no. 1 (2020): 55-65, https://doi.org/10.21831/diklus.v4i1.30263.

22 Suradi, A. (2018). Teori Kites dalam Pola Asuh Anak. Muróbbî: Jurnal Ilmu Pendidikan, 2(1), 17-34. https://doi.org/10.52431/murobbi.v2i1.121 
Study from Home (belajar dari rumah), di mana orang tua sebagai pengganti instrukur untuk mengarahkan anak selama sistem pembelajaran. Dalam melakukan SFH berupaya untuk memanfaatkan ilmu teknologi untuk menyikapi masalah pembelajaran dari rumah dengan cara memberikan materi dan tugas ilustrasi di Web. Namun hal tersebut tidaklah selalu berjalan dengan baik, terdapat banyak kendala dalam pelaksanaanya, seperti kuota dan sinyal yang tak memadai, bahkan beberapa anak tidak mempuyai gadget (telepon) yang baik, sehingga banyak pembelajaran tidak tersampaikan dengan baik, sehingga banyak anak yang kurang mengerti dan merasa tidak terbimbing dengan baik dalam memahami pelajaran disekolah. ${ }^{23}$

Dalam membimbing anak pada masa Study From Home selama pandemi Covid-19 adalah tentang bagaimana cara orang tua untuk memberikan semangat, dukungan, serta motivasi kepada anak agar mereka tetap semangat dalam belajar di rumah, memperhatikan tugasnya dan memberikan jadwal harian kepada mereka, menemani kegiatan pembelajaran mereka atau memberikan peluang kepada mereka untuk belajar sambil bermain supaya mereka tidak bosan. ${ }^{24}$ Dengan cara ini peran orang tua sangat besar dalam membimbing anak selama pandemi Coronavirus dan orang tua harus selalu ada untuk mereka. Oleh karena itu orang tua harus mengosongkan waktu untuk membimbing pembelajaran mereka.

Perkembangan teknologi di era digital saat ini semakin berpengaruh terhadap perkembangan anak. Teknologi telah sedikit banyak berdampak negative dalam pendidikan maupun sosiala anak. Namun dampak buruk yang ditimbulkan oleh kemajuan zaman juga membawa hal positif. Oleh karena itu, peran orang tua dalam mendidik anak zaman ini diharapkan dapat mengetahui hal-hal yang positif maupun negatif dari perkembangan teknologi.

Di Desa Pakuniran Kecamatan Pakuniran Kabupaten Probolinggo untuk menghadapi pandemi Corona Virus-19 sehingga pendidikan dilakukan secara daring. Dari hasil wawancara dan penelitian orang tua melakukan bimbingan secara khusus dirumah sebagai berikut:

Pertama, membersamai anak melakukan pembelajaran dimulai dari pembelajaran berlangsung hingga selesai kegiatan pembelajaran dari jam

${ }^{23}$ Haerudin et al., "Pembelajaran Di Rumah Sebagai Upaya Memutus Covid-19," Pembelajaran Di Rumah Sebagai Upaya Memutus Covid-19, no. May (2020): 1-12.

${ }^{24}$ Farida Nur Aziza and Muhammad Yunus, "Peran Orang Tua Dalam Membimbing Anak Pada MasaStudy From HAziza, F. N., \& Yunus, M. (2020). Peran Orang Tua Dalam Membimbing Anak Pada MasaStudy From Home Selama Pandemi Covid 19. Konferensi Nasional Pendidikan, 19-21.Ome Selama Pandemi Covid 19," Konferensi Nasional Pendidikan, 2020, 19-21. 
07.00 hingga jam 10.00 WIB, agar mereka tidak menyalahgunakan gadget kecuali untuk menggunakan media pembelajaran saat kegiatan Study From Home (belajar dari rumah).

Kedua, membimbing anak ketika mengerjakan tugas online dari guru melalui Web, baik dari link google yang berisi berbagai informasi tentang pembelajaran maupun media sosial yang berupa Whatsapp yang digunakan untuk mengirim tugas, serta mengajari mereka cara mengirim tugas kepada guru dengan menggunakan kalimat dan bahasa yang baik.

Ketiga, mengawasi serta membatasi anak ketika bermain gadget diluar kegiatan Studi From Home, seperti mengawasi ketika menggunakan aplikasi youtube dengan menonton konten yang ia inginkan. Dalam hal ini, orang tua harus mengetahui konten apa saja yang ditonton sehingga tidak menonton konten yang tidak baik atau yang tidak sesuai dengan usia anak. Untuk itu, orang tua juga harus memberikan waktu satu jam saja bagi anaknya untuk menggunakan gadget.

\section{Sikap orang tua dalam menghadapi perkembangan teknologi terhadap anak}

Orang tua harus mampu mengikuti perkembangan dunia digital bahkan harus lebih menguasai dibandingkan dengan penguasaan anak terhadap penggunaan media digital. Pembatasan atau pemberian aturan pun harus jelas dan konsisten terhadap penggunaan media digital, anak harus diberikan contoh dan mendapatkan edukasi sebelum mereka menggunakan media digital. ${ }^{25}$ Zaman teknologi yang semakin canggih memiliki dampak yang sangat penting di berbagai bidang masyarakat, termasuk pendidikan, ekonomi dan secara mengejutkan dalam perilaku dan efek yang berbeda. Dalam membimbing dan mendidik anak untuk menjadi generasi yang baik maka diperlukan pola pendekatan orang tua untuk memudahkan proses pembentukan generasi yang baik. ${ }^{26}$

Jika penggunaan gadget digunakan oleh anak-anak biasanya dibatasi dan penggunaannya hanya sebagai media pembelajaran, bermainmain dan menonton animasi, penggunaannya dapat memiliki waktu yang berbeda dan bervariasi intensitas penggunaan antara anak-anak dengan anak dewasa. Berbeda dengan anak yang sudah dewasa biasanya menggunakaan gagdget untuk berkomunikasi. seperti Whatshapp,

\footnotetext{
25 Jatut Yoga Prameswari and Dewi Indah Susanti, "PERKEMBANGAN TEKNOLOGI DAN INFORMASI" 04, no. 04 (2021): 336-45.

26 Hasan Baharun and Febri Deflia Finori, "Smart Techno Parenting: Alternatif Pendidikan Anak Pada Era Teknologi Digital," Jurnal Tatsqif 17, no. 1 (2019): 52-69, https://doi.org/10.20414/jtq.v17i1.625.
} 
Facebook dan lain-lain, mencari informasi atau browsing di internet, menonton youtobe untuk mencari konten yang ia inginkan, bermain game baik yang online atau offline ataupun yang lainnya.

Gadget memiliki pengaruh besar terhadap kehidupan manusia, demikian pula terhadap anak-anak. Dari segi psikologis, masa kanakkanak adalah masa keemasan dimana anak-anak belajar mengetahui apa yang belum diketahuinya. Jika masa kanak-kanak sudah mencandu dan terkena dampak negative oleh gadget, maka perkembangan anakpun akan terhambat, karena pengalaman masa kecil mempunyai pengaruh yang yang kuat terhadap perkembangan berikutnya. ${ }^{27}$

Sebenarnya gadget bukan hanya berdampak negatif akan tetapi juga ada hal-hal positif yang dapat diambil dalam penggunaanya. Gadget memiliki dampak positif bagi anak jika digunakan mencari informasi tambahan sebagai sarana penunjang belajar, dan menumbuhkan permainan dalam membaca, sains dan berpikir kritis (untuk situasi ini anak akan muncul gagasan ketertarikan pada sesuatu yang akan membuat anak sadar akan perlunya belajar tanpa perlu di paksa), serta tidak menggunakan gadget terlalu lama, agar tidak mengalami kecanduan, selain dampak positif ada pula dampak negative dari gadget yaitu anak menjadi malas melakukan aktifitas fisik, anak mudah menjadi marah, saat diberi tahu anak mudah membangkang, anak mudah meniru dan sering meniru tingkah laku yang ada pada game, sering berbicara sendiri pada gadget, dan membuat mata anak menjadi sakit jika terlalu lama memainkan gadget. ${ }^{28}$ dan dapat mempengaruhi perilaku anak (seperti contoh anak bermain game yang memiliki unsur kekerasan yang akan mempengaruhi pola perilaku dan karakter yang dapat menimbulkan tindak kekerasan terhadap teman). ${ }^{29}$

Untuk itu sebaiknya orang tua mengawasi anak ketika anak menggunakan gadget, pada situasi saat ini pembelajaran dilakukan secara online sehingga orang tua perlu mengawasi dan memberikan batasan penggunan gadget pada anak. Jadi orang tua memberikan memberikan gadget untuk anak-anak harus sesuai dengan kebutuhan mereka seperti yang ditunjukkan pada waktu mereka harus digunakan, berdampak buruk

27 Indian Sunita and Eva Mayasari, "Pengawasan Orangtua Terhadap Dampak Penggunaan Gadget Pada Anak," Jurnal Endurance 3, no. 3 (2018): 510, https://doi.org/10.22216/jen.v3i3.2485.

${ }^{28}$ Layyinatus Syifa, Eka Sari Setianingsih, and Joko Sulianto, "Dampak Penggunaan Gadget Terhadap Perkembangan Psikologi Pada Anak Sekolah Dasar," Jurnal Ilmiah Sekolah Dasar 3, no. 4 (2019): 538, https://doi.org/10.23887/jisd.v3i4.22310.

29 Junierissa Marpaung, "Pengaruh Penggunaan Gadget Dalam Kehidupan," KOPASTA: Jurnal Program Studi Bimbingan Konseling 5, no. 2 (2018): 55-64, https://doi.org/10.33373/kop.v5i2.1521. 
pada anak-anak bergantung pada bagaimana orang tua memberikan gadget dan mengawasi anak-anak saat bermain gadget. Agar berdampak positif dari penggunaan gadget, orang tua harus memahami substansi yang terkandung di dalamnya, dan menguasai penggunaan aplikasi apa pun di dalam gadget.

Dari hasil penelitian di Desa Pakuniran, Kecamatan Pakuniran, Kabupaten Probolinggo bahwa orang tua menyikapi perkembagan teknologi saat ini, harus menguasai teknologi media digital terutama gadget, orang tua juga harus mengetahui isi konten apa saja yang ada di dalam gadget tersebut. Orang tua di Desa Pakuniran juga memberikan kesempatan kepada anak-anak untuk bermain game konvensional bersama teman-temannya, sehingga anak-anak lupa terhadap gadget dan akan membangun hubungan sosial. Melalui kegiatan bermain anak akan mengeksplorasi objek-objek yang ada di lingkungan masyarakat pakuniran. Dari hasil penelitian dapat dilihat dari hal-hal berikut ini:

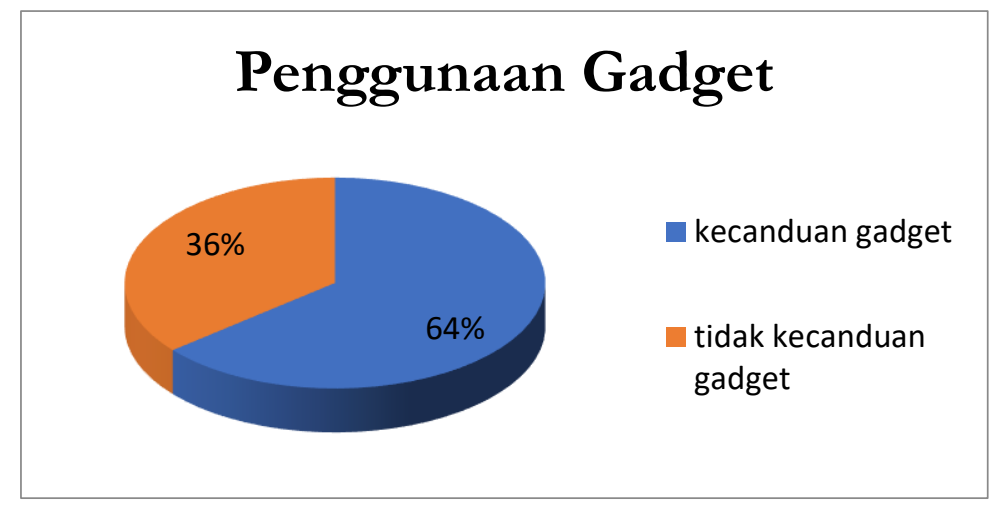

\section{Gambar. 1 Penggunaan Gadget}

Pertama, dari hasil penelitian dan wawancara bahwa 64\% anak-anak bergantung pada gadget, hal ini terjadi diantara orangtua yang pendidikannya di bawah sekolah menengah/SMA, tidak menutup kemungkinan yang berpendidikan tinggi tidak memiliki anak yang bergantung pada gadget, akan tetapi hal ini akan terjadi biasanya orang tua yang berpendidikan tinggi sibuk bekerja sehingga tidak ada cara untuk menangani anak, kurangnya pengawasan dan pendekatan terhadap anak. Ini membuktikan bahwa tingkat pendidikan sangat berpengaruh terhadap anak.

Kedua, dari 100\% hanya 36\% di Desa Pakuniran anak yang tidak kecanduan gadget, sebab analisis data yang dilakukan dapat memperoleh bahwa orang tua yang berlulusan S1 keatas dapat mengetahui cara berfikir seseorang, bagaimana ia akan menyikapinya di era globalisasi ini. 
Semakin tinggi orang tua dalam pendidikan maka semakin banyak pengetahuan yang ia peroleh.

Ketiga orang tua di Desa Pakuniran ini menyikapi dengan berbagai sikap atau perilaku, dari hasil pengamatan bahwa dilakukan oleh para orang tua di lingkungkungan rumah di Kota Kecamatan Pakuniran kabupaten Probolinggo, yaitu mereka yang memiliki anak-anak yang masih duduk di bangku taman kanak-kanak (TK) maupun Tingkat Dasar memilih untuk menerapkan system reward berurusan dengan point. Point-point yang dikumpulkan oleh anak akan diberi reward ketika melakukan hal yang baik, reward akan diberikan sesuai dengan jumlah point yang dikumpulkan, kumpulan point tersebut akan ditukar untuk mendapat reward ada yang menerima berupa uang, membeli buku cerita ataupun jalan-jalan ketempat wahana bermain anak (wisata). Apabila anak melakukan perilaku buruk maka poit-point tersebut akan dihilangkan, jika itu terjadi orang tua di Desa Pakuniran akan menjelaskan apa yang dilakukan anak.

Desa Pakuniran, Kecamatan Pakuniran, Kecamatan Pakuniran, Kabupaten Probolinggo, orang tua memberikan reward kepada anakanak jika anak memeatuhi arahan orangtua. Penghargaan dalam pengertian bahasa Indonesia disebut kehormatan. Penghargaan merupakan bentuk apresiasi terhadap pelaku kebaikan, siapapun itu. Bentuk penghargaan sendiri sangat variatif, bisa dalam bentuk materi atau non materi, prinsipnya adalah untuk membangkitkan semangat anak yang telah berhasil melakukan kebaikan karena secara naluri siapapun yang telah melakukan kebaikan sealu ingin diberikan penghargaan dan ini adalah bagian dari psikologi manusia sebagai makhluk. Maka dari itu Allah melalui Al-qur'an juga memberikan apresiasi kepada manusia atas kebaikan yang telah mereka lakukan. ${ }^{30}$

Artinya: "Barang siapa yang melakukan kebaikan seberat dzarrahpun, niscaya dia akan melihat (balasannya), dan barang siapa yang melakukan kejahatan seberat dzarrahpun, niscaya dia akan melihat balasannya." (Q.S. al-Zalzalah: 78)

Jadi ayat diatas menjelaskan bahwa didalam islam penghargaan sebagai proses pembelajaran untuk menjadikan anak lebih semangat dalam belajar dan mendapatkan motivasi dalam melakukan kegiatan belajar, agar proses pembelajaran lebih menarik. Pemberian penghargaan jauh lebih efektif diterapkan bagi anak daripada hukuman atau punishment. Sebab, adanya punishment merupakan perlakuan yang tidak

\footnotetext{
30 Wahyudi Setiawan, "Reward and Punishment Dalam Perspektif Pendidikan Islam," AL-MURABBI: Jurnal Studi Kependidikan Dan Keislaman 4, no. 2 (2017): 184-201, https://doi.org/10.53627/jam.v4i2.3171.
} 
menyenangkan bagi anak. ${ }^{31}$ Dalam hal ini, penghargaan atau reward yang dimaksud dapat berupa uang atau benda lainnya, bukan hanya benda saja akan tetapi dapat berupa pujian dan lain sebagainya, akan tetapi di Desa Pakuniran Kecamatan pakuniran Kabupaten Probolinggo cara memberikan reward kurang tepat, salah satunya ialah membeli mainan mahal atau makanan mewah yang anak sukai. Dari hal itu membuat anak akan menjadi manja. Agar lebih efektif, pemberian reward dapat dilakukan dengan cara seperti berikut:

Pertama, mengajak anak untuk membeli buku cerita, diajak jalanjalan ketoko buku untuk membeli buku yang ia sukai. Kedua, menonton sesuatu di youtobe yang bernilai sehingga mampu mengasah kemampuan imajinasi anak, salah satu contohnya yaitu dengan konten yang orang tua di desa pakuniran memberikan izin terhadap anak untuk melihat video kartun akan tetapi audionya berisi murottal Qur'an dan menonton konten kartun yang berisi musik anak.

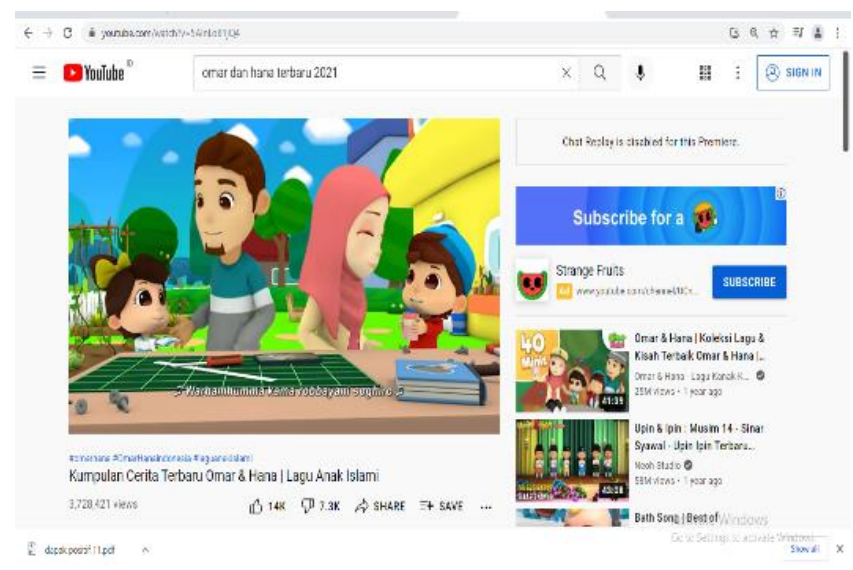

Gambar. 2 Contoh video animasi islami Omar dan Hana bttps://youtu.be/ 5 AInLoB1jQ4

31 Chusnul Muali and Helmiyatus Sa'adah, "Konsep Punishment Perspektif Ibnu Sahnun (Analisis Kitab Adab Al Muallimin)," Tafaqqub: Jurnal Penelitian Dan Kajian Keislaman 6, no. 2 (2018): 228-50, https://doi.org/10.52431/tafaqquh.v6i2. 


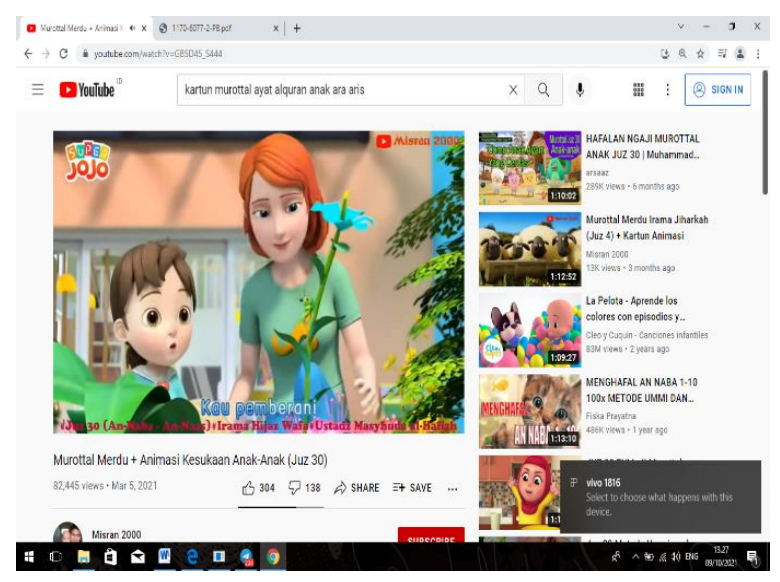

\section{Gambar. 3 Contoh vidio Animasi murottal}

bttps://youtu.be/GB5D45 S444

Gambar film animasi islami omar dan Hana ini berasal dari negeri tetangga, Malaysia. Berbeda dengan Upin-Ipin, animasi ini disajikan dengan lagu yang mudah diingat oleh anak-anak, Kontennya beragam mulai dari do'a sehari-hari hingga belajar huruf hijjaiyah bahkan balita pun bisa diajak untuk menonton animasi ini, karena disajikan dengan sangat sederhana dan mudah dimengerti, oleh karena itu orang tua memiliki peran untuk mendorong dan mengarahkan anak menuju kejenjang pendidikan, maka dari itu orang tua akan menjadi seorang pendidik pertama bagi anak. Hal ini menjadi salah satu keunikan dari penelitian yang dilakukan oleh peneliti.

\section{Penutup}

Fokus penelitian ini adalah kajian terhadap peran orang tua dalam menyikapi dampak perkembangan teknologi bagi anak. Dari penelitian yang dilakukan di desa Pakuniran, ditemukan bahwa masih terdapat anak yang kecanduan gadget sehingga tidak peduli terhadap lingkungan sekitarnya. Dalam menyikapi permasalahan tersebut, dibutuhkan peran orang tua untuk mengawasi dan mendampingi anak selama menggunakan gadget, terutama ketika Study From Home secara online.

Peran orang tua sangat berpengaruh terhadap dampak perkembangan teknologi saat ini. Orangtua hendaknya dapat menguasai semua penggunaan serta pemahaman terhadap aplikasi yang ada di dalam gadget, terutama pada aplikasi youtobe yang saat ini banyak digunakan 
oleh anak-anak. Tidak hanya itu, orangtua dapat memberi reward edukatif kepada anak untuk mengalihkan perhatian anak dari pengaruh gadget. Reward edukatif ayang dimaksud antara lain mengajak anak untuk membeli buku cerita, menonton tayangan di youtobe yang mengasah kemampuan imajinasi anak, melihat video kartun murottal Qur'an dan menonton kartun yang berisi musik anak. Dari penelitian ini diperoleh implikasi bahwa perlu adanya pengawasan dan pendampingan yang intensif dari orang tua untuk mengurangi dan mencegah dampak negative gadget terhadap anak.

\section{Daftar Pustaka}

Akbar, Amin, and Nia Noviani. "Tantangan Dan Solusi Dalam Perkembangan Teknologi Pendidikan Di Indonesia." Prosiding Seminar Nasional Pendidikan Program Pascasarjana Universitas Pgri Palembang 2, no. 1 (2019): 18-25.

Asmawati, Luluk. "Peran Orang Tua Dalam Pemanfaatan Teknologi Digital Pada Anak Usia Dini." Jurnal Obsesi: Jurnal Pendidikan Anak Usia Dini 6, no. 1 (2021): 82-96. https://doi.org/10.31004/obsesi.v6i1.1170.

Aziza, Farida Nur, and Muhammad Yunus. "Peran Orang Tua Dalam Membimbing Anak Pada MasaStudy From HAziza, F. N., \& Yunus, M. (2020). Peran Orang Tua Dalam Membimbing Anak Pada MasaStudy From Home Selama Pandemi Covid 19. Konferensi Nasional Pendidikan, 19-21.Ome Selama Pandemi Covid 19." Konferensi Nasional Pendidikan, 2020, 19-21.

Baharun, Hasan, and Febri Deflia Finori. "Smart Techno Parenting: Alternatif Pendidikan Anak Pada Era Teknologi Digital." Jumal Tatsqif 17, no. 1 (2019): 52-69. https://doi.org/10.20414/jtq.v17i1.625.

Baharun, Hasan, Chusnul Muali, Muhammad Mushfi, El Iq, Fathor Rozi, Nafisatur Rodiah, Zainabal Munawaroh, and Siti Aminah. "Learning Strategies for Mobile-Assisted Seamless Learning: A Students 'Initial Perceptions" 536, no. Icsteir 2020 (2021): 55760.

Baharun, Hasan, Fathor Rozi, Muhammad Wisolus Sholihin, Moh Faisol, Aziz Marsida, Dahlan Abdullah, Nursan Junita, et al. "Learning Effectiveness Improvement Through Mobile Learning." Turkish Online Journal of Qualitative Inquiry 12, no. 4 (2021): 1661-65.

Bondy, Brigitta, Ute Klages, Franz Müller-Spahn, and Christoph Hock. "Cytosolic Free $[\mathrm{Ca} 2+]$ in Mononuclear Blood Cells from 
Demented Patients and Healthy Controls." European Archives of Psychiatry and Clinical Neuroscience 243, no. 5 (1994): 224-28. https://doi.org/10.1007/BF02191578.

Fredik Melkias Boiliu, Kaleb Samalinggai, Devi Wahyu Setiawati. "Peran Pendidikan Agama Kristen Di Era Digital Sebagai Upaya Mengatasi Penggunaan Gadget Yang Berlebihan Pada Anak Dalam Keluarga Di Era Disrupsi 4.0.” Jurnal DID ACGE 1, no. 1 (2020): 25-28.

Haerudin, Adinda Cahyani, Nur Sitihanifah, Rizky Nurul Setiani, Siti Nurhayati, Veronika Oktaviani, and Yuliani Indriani Sitorus. "Pembelajaran Di Rumah Sebagai Upaya Memutus Covid-19." Pembelajaran Di Rumah Sebagai Upaya Memutus Covid-19, no. May (2020): 1-12.

Hidayati, Rahma. "Peran Orang Tua : Komunikasi Tatap Muka Dalam Mengawal Dampak Gadget Pada Masa Golden Age." SOURCE : Jurnal Ilmu Komunikasi 5, no. 2 (2020): 1-10. https://doi.org/10.35308/source.v5i2.1396.

Huda, Irkham Abdaul. "Perkembangan Teknologi Informasi Dan Komunikasi (Tik) Terhadap Kualitas Pembelajaran Di Sekolah Dasar." Jurnal Pendidikan Dan Konseling (JPDK) 2, no. 1 (2020): 121-25. https://doi.org/10.31004/jpdk.v1i2.622.

Jannah, Nur, and Khoirul Anam. "Peran Orang Tua Dalam Pendidikan Karakter Berbasis Keluarga Di Masa Pandemi." Jurnal Studi Keislaman 12, no. 1 (2021): 95-115.

Lilawati, Agustin. "Peran Orang Tua Dalam Mendukung Kegiatan Pembelajaran Di Rumah Pada Masa Pandemi." Jurnal Obsesi: Jurnal Pendidikan Anak Usia Dini 5, no. 1 (2020): 549. https://doi.org/10.31004/obsesi.v5i1.630.

Mahmud, Eka, Fathor Rozi, Hefniy, Hasan Baharun, Agus Syakroni, Chusnul Muali, Romzatul Widad, Nur Azizah, Siti Aminatus Zuhriya, and Dahlan Abdullah. "The Effect of Using Edmodo Application on Students' Mastery Skill of Technology." Journal of Physics: Conference Series 1899, no. 1 (2021). https://doi.org/10.1088/1742-6596/1899/1/012157.

Marpaung, Junierissa. "Pengaruh Penggunaan Gadget Dalam Kehidupan." KOPASTA: Jurnal Program Studi Bimbingan Konseling 5, no. 2 (2018): 55-64. https://doi.org/10.33373/kop.v5i2.1521.

Muali, Chusnul, and Helmiyatus Sa'adah. "Konsep Punishment Perspektif Ibnu Sahnun (Analisis Kitab Adab Al Muallimin)." Tafaqquh: Jurnal Penelitian Dan Kajian Keislaman 6, no. 2 (2018): 228-50. https://doi.org/10.52431/tafaqquh.v6i2. 
Nasution, Robby Darwis. "Effect of the Development of Communication Information Technology on Local Cultural Existence." Jurnal Penelitian Komunikasi Dan Opini Publik 21, no. 1 (2017): 30-42.

Ningrum, Wahyu Relisa. "Peran Orangtua Dalam Menyikapi Dampak Media Sosial Terhadap Perkembangan Kepribadian Remaja Awal," 2018, 355-66.

Novianti, Ria, Febrialismanto Febrialismanto, Enda Puspitasari, and Hukmi Hukmi. "Meningkatkan Pengetahuan Orang Tua Dalam Mendidik Anak Di Era Digital Di Kecamatan Koto Gasib Kabupaten Siak Provinsi Riau." Riau Journal of Empowerment 3, no. 3 (2020): 183-90. https://doi.org/10.31258/raje.3.3.183-190.

Prameswari, Jatut Yoga, and Dewi Indah Susanti. "PERKEMBANGAN TEKNOLOGI DAN INFORMASI” 04, no. 04 (2021): 336-45.

Rachmawati, and Tutik. "Metode Pengumpulan Data Dalam Penelitian."

Universitas Katolik Parabyangan 1, no. 1 (2017): 1-3. http:/ / ciputrauceo.net/blog/2016/2/18/metode-pengumpulandata-dalam-penelitian.

Rijali, Ahmad. "Analisis Data Kualitatif." Alhadharah: Jurnal Ilmu Dakwah 17 , no. 33 (2019): 81. https://doi.org/10.18592/alhadharah.v17i33.2374.

Rozi, Fathor, Maghfur Ramdlani, Faizun Najah, Noer Azizah, Harisatun Niswa, Moch Abdillah, and Fakhrur Rozi. "Distance Learning and Independent Learning of Students in Higher Education." Journal of Physics: Conference Series 1899, no. 1 (2021). https://doi.org/10.1088/1742-6596/1899/1/012177.

Ruli, Efrianus. "Tugas Dan Peran Orang Tua Dalam Mendidk Anak." Jurnal Edukasi Nonformal 1, no. 2 (2020): 143-46. https://ummaspul.e-journal.id/JENFOL/article/view/428.

Setiawan, Daryanto. "Dampak Perkembangan Teknologi Informasi Dan Komunikasi Terhadap Budaya." JURNAL SIMBOLIKA: Research and Learning in Communication Study 4, no. 1 (2018): 62. https://doi.org/10.31289/simbollika.v4i1.1474.

Setiawan, Wahyudi. "Reward and Punishment Dalam Perspektif Pendidikan Islam." AL-MURABBI: Jurnal Studi Kependidikan Dan Keislaman 4, no. 2 (2017): $184-201$. https://doi.org/10.53627/jam.v4i2.3171.

Sunita, Indian, and Eva Mayasari. "Pengawasan Orangtua Terhadap Dampak Penggunaan Gadget Pada Anak." Jurnal Endurance 3, no. 3 (2018): 510. https://doi.org/10.22216/jen.v3i3.2485.

Suradi, A. (2018). Teori Kites dalam Pola Asuh Anak. Muróbbî: Jurnal Ilmu 
https://doi.org/10.52431/murobbi.v2i1.121

Syifa, Layyinatus, Eka Sari Setianingsih, and Joko Sulianto. "Dampak Penggunaan Gadget Terhadap Perkembangan Psikologi Pada Anak Sekolah Dasar." Jurnal Ilmiah Sekolah Dasar 3, no. 4 (2019): 538. https://doi.org/10.23887/jisd.v3i4.22310.

Wahid, Abd Hamid, Fathor Rozi, Hasan Baharun, Wiwin Hidayati, and Abdul Talib Bon. "Information Technology in the Development of Language Aspects of Early Childhood," 2021.

Wijayanto, Arif. "Peran Orangtua Dalam Mengembangkan Kecerdasan Emosional Anak Usia Dini." Diklus: Jurnal Pendidikan Luar Sekolab 4, no. 1 (2020): 55-65. https://doi.org/10.21831/diklus.v4i1.30263. 